\title{
The Effect of School Culture, Horizontal Communication, Knowledge Management, and Work Motivation of State Junior High Schools Teacher Performance in Medan
}

\author{
Muhammad Yunus Nasution* Zainuddin Abdul Muin Sibuea \\ State University of Medan, J1. Willem Iskandar Psr. V Medan, Indonesia
}

\begin{abstract}
This study aims to investigate the effect of school culture, horizontal communication, management knowledge, and work motivation on teacher performance. The population in this study is 237 mathematics teachers in state junior high school and the sample consisted of 149 teachers. The results show that: school culture affects work motivation with a path coefficient of 0.318 , horizontal communication influences work motivation with a path coefficient of 0.422 , knowledge management affects work motivation with path coefficients of 0.233 , school culture influences teacher performance with a path coefficient of 0.238 , horizontal communication influences teacher performance with a path coefficient of 0.315 , knowledge management affects the performance of teachers with a path coefficient of 0.169 , and work motivation affects the performance of teachers with a path coefficient of 0.306 . Based on these findings, it can be concluded that the strengthening of school culture, horizontal communication, and management knowledge causes higher work motivation which make performance better.

Keywords: School culture, horizontal communication, knowledge management, work motivation, performance DOI: $10.7176 / \mathrm{JEP} / 11-15-11$
\end{abstract}

Publication date:May $31^{\text {st }} 2020$

\section{INTRODUCTION}

In carrying out of organization, teacher has an important role for the effectiveness of an organization, especially in schools. A teacher is now required to have a dynamic mindset and behavior in line with the development of knowledge and technology. School is a small community that is very important to contribute to the advancement of schools in general in order to achieve the expected education. Good performance will produce good goals as well. Teacher performance in an organization is highly prioritized, for the sake of creating a conducive atmosphere for the progress of school organizations.

Good performance can benefit all members of the organization. Performance can be interpreted as an effort to gather strength to complete work in the organization to obtain maximum results Teachers in carrying out their tasks really need to be considered and evaluated their performance, because they have professional assignments which means it can only be done with specific competencies obtained through educational programs. Teacher performance is the ability shown by the teacher in carrying out the task or work. Based on these things, a teacher must be able to sort and choose when to empathize with students, when it is critical, when to accept or reject. In other words, a teacher must be able to play a dual role. This dual role can be realized differently according to the situation and conditions.

The quality of education in State Junior High Schools in Medan is still considered low because graduates are not yet ready to enter further education due to the lack of competencies. The skills acquired in educational institutions are not sufficient to be used independently, it only transfers of knowledge which results students are not innovative, creative or even good at dealing with issues around their environment. The lack of competence and skills possessed by teachers affect the quality of teacher performance in learning. Teachers are less creative and innovative so that it is boring for students to obtain knowledge from teachers, because teacher performance is still at low levels.

Based on interviews with several school principals, August 23, 2018, it is concluded that there are problems with teacher performance. Many teachers still do not have high performance. There are still some teachers in teaching still using conventional approaches. They do not use methods that make students active. As a result, teaching process is not optimal in carrying out their assignments both in the classroom and outside the classroom. The effect of low teacher performance affects the student's learning achievement. The energy factor of the principal will be able to reduce the enthusiasm and work ability of teachers and this is very influential on the duty that is so much charged to teachers.

Based on observations in some state junior high school, there are still many teachers who have attitudes, values and ethics that are not in line with expectations. This is proven by the fact that there are still many teachers who do not carry out their tasks as they should. They are not punctual in the teaching-learning process in the class, postpone the implementation of the teaching-learning process, prioritizing additional tasks rather than their main duties as teachers. It can reduce the quality teacher's work. Although most of them have educator certificates, but their performance, productivity, work performance, work effectiveness is still not optimal. 
Furthermore, the relationship among of the teachers deals with kinship, family relations that work together in discussing methods of learning in the classroom or other problems. This is evidenced by the rarely occurring communication among teachers in discussions involving learning in class. Teachers must communicate with one another. They should become more solid and united, in carrying out the process of teaching students. It makes teacher to have more abilities, mastery, and skill. This view is similar to that expressed by Beaven (2003:88) that a teacher must exchange ideas with other teachers.

Indrafachrudi (2000:52) describes two categories which influence the performance namely: Internal factors and external factors. Internal factors are factors that originate from within a person that can affect one's performance in carrying out their work, they are motivation and interests, talents, character, traits, age, gender, education, and experience, while external factors are factors that come from outside oneself that can affect their performance such as physical environment, facilities and infrastructure, benefits, atmosphere, policies, administrative systems and so on. Internal factors are work motivation, both individually and as an institution as a professional entity that requires awareness, and stronger responsibilities in carrying out their roles and functions as a teacher.

Work motivation is an important personality characteristic in an organizational environment. It is characterized by the encouragement of individual to excel others in accordance with a set of applicable standards and strive for success. Motivation is a commodity that needed by everyone including teachers. Teachers will work better if they are truly motivated. Teachers who have high work motivation will make a valuable contribution to education. The strength or weakness of work motivation depends on the amount of expectations to be achieved, the strength of the basis that gives rise to motivation and the amount of satisfaction obtained. People who have high work needs are happy to assume responsibility, like challenging work, have competition, be proud of their work and confident in their abilities. Mohammed and Doghan's research (2015) shows that there is a direct relationship between work motivation and performance. Teachers will work better if they are truly motivated. Teachers who succeed because of work motivation will make a valuable contribution to education.

Knowledge management is also as important as work motivation which can improve teacher performance. Teachers need knowledge because they are faced with a variety of activities that involve a lot of interaction with others, so it is needed. Educational management refers to the process of planning, organizing, directing, and controlling educational resources to achieve educational goals effectively and efficiently. Thus, knowledge management describes cognitive abilities in the process of planning, organizing, directing, and controlling educational resources to achieve educational goals effectively and efficiently.

Furthermore, the variables that affect teacher performance are horizontal communication. Horizontal communication is a variable that comes from outside a teacher. It determines teacher performance. Teachers who have the ability to communicate horizontally in carrying out their duties will realize that they have a great responsibility in achieving educational goals. Conversely, if a school principal does not have the ability to communicate horizontally with the teacher in carrying out their duties and obligations, it will have implications for the decline in teacher performance, even further will have an impact on the deteriorating quality of human resources.If horizontal communication among teachers is able to be synergized, it will have a positive impact on their performance. It encourages the enthusiasm of the teacher's work which in turn can spur their performance.

In line with Riyadi et al (2017), it is also known that communication influences work motivation and has an influence on teacher performance. There is an effect of communication on job satisfaction for lecturers, as well as an increase in motivation among lecturers, especially motivation in work. Professional lecturers who always perform well must be able to be maintained and improved by paying attention to the components that are motivated by their work so that their performance increases. In line with the research conducted by Wijaya and Herminingsih (2015), it is also known that communication influences motivation and has an influence on teacher performance. Organizational communication, work motivation and compensation together have positive and significant effects on teacher performance.

School culture is also thought to be worth investigating as a variable that can affect performance. Jumari et al (2013) reveals that there is a positive and significant influence of organizational culture on the teaching performance of teachers in Sate Vocational School South Denpasar with a determination of 39.6\% and an effective contribution of $17.6 \%$. Liana (2012) explains that there is a significant influence of organizational climate on teacher performance. School culture is the soul of a school that gives meaning to the educational activities of the school, if school culture is weak, and then it is not conducive to the formation of an effective school. Conversely a strong school culture is a facilitator for effective school improvement. School culture can influence several variables that can make schools effective and performance among teachers' increases namely work performance and motivation. If school culture is good, it is possible to increase work motivation which ultimately improves teacher performance. Colquit (2009) in Integrative Model of Organizational Motivation states that performance variables and motivational variables are directly influenced by organizational culture

Based on the theories described above, it is necessary to conduct this research in order to solve the problem of teacher performance which has so far been ineffective at state junior high schools in Medan. The variables that 
are considered the most dominant to solve the problems above are used as variables in this study, namely School Culture, Horizontal Communication, knowledge management, work motivation, and performance of teachers at state junior high schools in Medan.

\section{LITERATURE REVIEW}

\subsection{Teachers Performance}

The term teacher performance can be interpreted with work performance or actual achievement achieved by someone. National Education Department (2004:4) defines performance with work performance. Performance leads to an effort in order to achieve better work performance, other words performance is one's success in carrying out a job. According to Robbins (2009) performance is defined as what is done and what is not done by employees. Rivai (2006) states that performance is an achievement achieved by someone in carrying out their duties or work in accordance with the standards and criteria set for the job.

It is concluded that performance is an achievement produced by someone in the form of achievement in accordance with established standards. Operational performance of a teacher is an achievement produced by a teacher from achievement in accordance with established standards. This research uses an indicator of teacher performance which is measured through planning learning activities, implementing learning activities, and evaluating learning.

\subsection{Work Motivation}

Basically, someone works because of the desire to meet his life's needs. Motivation is an encouragement factor that can trigger a sense of enthusiasm and is also able to change the behavior of humans or individuals to lead to things that are better for themselves. According to Hasibuan, motivation comes from the Latin word movere which means encouragement or move. Sutrisno (2013:109) states that motivation is an actor who pushes someone to do a certain activity. It is often interpreted as a factor driving a person's behavior. Mangkunegara (2012:61) also states motivation is a condition or energy that moves employees who are directed to achieve organizational goals. Hamalik (2004: 173) explains motivation can be basic or internal impulses and intensive outside the individual or gift. While Nawawi (2003) states motivation is a condition that encourages or becomes a reason for someone to do an activity that takes place consciously, in order to achieve company goals. There are several objectives that can be obtained.

Based on some of the explanations above, it can be concluded that work motivation is a condition or force that drives a person to carry out certain activities in order to achieve a goal. Teacher's work motivation is the overall driving force within a teacher who is endeavored to guarantee the continuity of his work by giving direction so that the goals of work that have been formulated can be achieved. Indicators of teacher work motivation are: the desire to succeed, the encouragement and need to work, the appreciation of work, the existence of a conducive environment, and pleasant working conditions

\subsection{Knowledge Management}

Management can be defined as an effort to manage resources to achieve the expected goals. Humans need knowledge because they are faced with a variety of activities that involve a lot of interaction with others, so knowledge management is needed. Hasibuan (2011:1) Management is the science and art of regulating the process of utilizing human resources and other resources effectively and efficiently to achieve a certain goal. It is the control and utilization of all factors and resources that according to a plan are needed to achieve or complete a particular work goal.

In the world of education, management education plays a very important role. Basically management of learning is the regulation of all learning activities that are categorized in the core curriculum. In other words, Education Management is an activity or a series of activities in the form of a business management process in the collaboration of a group of people who are members of an educational organization, to achieve the educational goals that have been previously determined, to be effective and efficient.

Siagian (2005:17) explains that the management function is planning, organizing, motivating, monitoring and evaluating. Furthermore, knowledge refers to everything that is known to individuals. Thus, knowledge management describes cognitive abilities in the process of planning, organizing, directing, and controlling educational resources to achieve educational goals effectively and efficiently. In accordance with its nature, knowledge is a cognitive ability related to affective abilities, and psychomotor abilities that individuals obtain through education. Sagala (2006:15) management principally carries out the functions of planning, implementation and control into a series of decision-making activities that are fundamental and comprehensive in the process of efficiently utilizing all resources accompanied by the determination of how to implement them by all levels in an organization to achieve organizational goals. Manullang (2004:10) states management is the art and science of planning, organizing, directing, coordinating and controlling to achieve predetermined goals.

From some of the explanations above, it can be concluded that knowledge management in this study is the 
cognitive ability of teachers in the process of carrying out tasks to achieve educational goals effectively and efficiently with indicators of planning, organizing, and directing.

\subsection{Horizontal Communication}

Communication usually occurs in commission meetings, personal interactions, telephone conversations, memos and notes, social activities, and quality circles. Horizontal communication is needed to save time and facilitate coordination to speed up action (Robbins, 2005). It eases of coordination process because of the relatively similar level, background of knowledge and experience between the communicating parties and the presence of a nonstrict formal structure. Horizontal or lateral communication, namely communication between peers such as from employees to employee. The message in this communication can flow in the same section within the organization or flow between sections. This horizontal communication facilitates the exchange of knowledge, experience, methods, and problems. This helps the organization to avoid some problems as well as build morale and job satisfaction.

Horizontal communication is designed to provide feedback about how well the organization is functioning. Subordinates are expected to provide information about their achievements and organizational practices and policies. According to Effendy (2003:124) horizontal communication is horizontal communication, between staff members, employees and so on. Miftah (2007:188) argues that horizontal communication is the sending and receiving of news or information carried out between various officials who have the same position. The purpose of this communication is to coordinate the horizontal dimension of communication in part can be done in writing and oral.

Based on some of the explanations above, it can be concluded horizontal communication is communication that involves between individuals or groups at the same level. The purpose of horizontal communication includes coordinating work assignments, sharing information about plans and activities, solving problems that arise between people who are at the same level, to gain mutual understanding. In this study the indicators of horizontal communication are: coordinating work assignments, openness in informing problems, sharing information about plans and activities, gain mutual understanding, and reconcile or negotiate and mediate differences.

\subsection{School Culture}

School as an organization has its own culture that is formed and influenced by values, perceptions, habits, educational policies, and the behavior of the people who are in it. School is a social system that has a unique organization and patterns of social relations in among its members. It is called school culture. According Zamroni (2003:149), habits, values, norms, rituals, myths that are formed in the long journey of school are called school culture. A strong organizational culture affects every behavior. It does not only have an impact on the benefits of school organizations in general but also have an impact on the development of the ability and effectiveness of teacher work itself.

According to Robbins (2003:721) organizational culture is a systems that shared by members that distinguishes the organization from other organizations. Organizational culture includes two different attributes. Firstly, intensity which means boundaries or stages when the members of the organization agree on the norms, values, or other cultural contents related to the organization or unit. Secondly, integrity which means the boundaries or stages when units are in an organization participates in providing a general culture. These two attributes are sufficient to explain the culture created by the organization that influences employee behavior and the implementation of organizational culture that is influenced by personal culture. Davis (2000) organizational culture is a unit of norms consisting of beliefs, attitudes, values, and patterns of behavior carried out by people in the organization, and all of them affect the performance of the organization.

Based on some of the explanations above, it can be concluded that school culture is a set of values, norms, assumptions, beliefs, principles, characteristics, and habits or regulations that apply in an organization that regulates and directs the behavior of members of the organization in an effort to do a job in solving problems. school culture indicators used are innovation and risk taking, aggressive at work, team orientation, and orientation to results

\section{RESEARCH METHODOS}

\subsection{Place and Time of Research}

This research is conducted at state junior high school in Medan. The researcher has coordinated with the teachers and the head of the local office where junior high schools in Medan experiences a decline in the performance of teachers, especially mathematics teacher. The population in this study is 237 mathematics teachers in state junior high school and the sample consisted of 149 teachers.

\subsection{Data Analysis Technique}

Analysis of the data used in this study includes descriptive analysis, test requirements analysis, and hypothesis 
testing. In accordance with the research hypothesis and research objectives, hypothesis testing is carried out using path analysis.

\subsection{Research Hypothesis Test}

To test the hypothesis used path analysis with the help of a computer program SPSS for Windows version 25.0. In testing hypotheses used a significance level of $\alpha$ of 0.05 . In connection with the use of path analysis must first be described in a diagrammatic structure of the causal relationship with the cause and effect variables.

\subsection{Research Result}

The description of data presented in this section includes data on school culture variables $\left(\mathrm{X}_{1}\right)$, horizontal communication $\left(\mathrm{X}_{2}\right)$, knowledge management $\left(\mathrm{X}_{3}\right)$, work motivation $\left(\mathrm{X}_{4}\right)$, and teacher performance $\left(\mathrm{X}_{5}\right)$. The data is the result of the quantification of respondents' answers to the questionnaire distributed to state junior high schools teachers in Medan. The number of questionnaires distributed is 149 sets according to the number of study samples. The Sub-Structure I model is the direct influence of school culture variables $\left(\mathrm{X}_{1}\right)$, horizontal communication $\left(\mathrm{X}_{2}\right)$, knowledge management $\left(\mathrm{X}_{3}\right)$, work motivation $\left(\mathrm{X}_{4}\right)$, and teacher performance. The model image is presented in Figure 1 below.

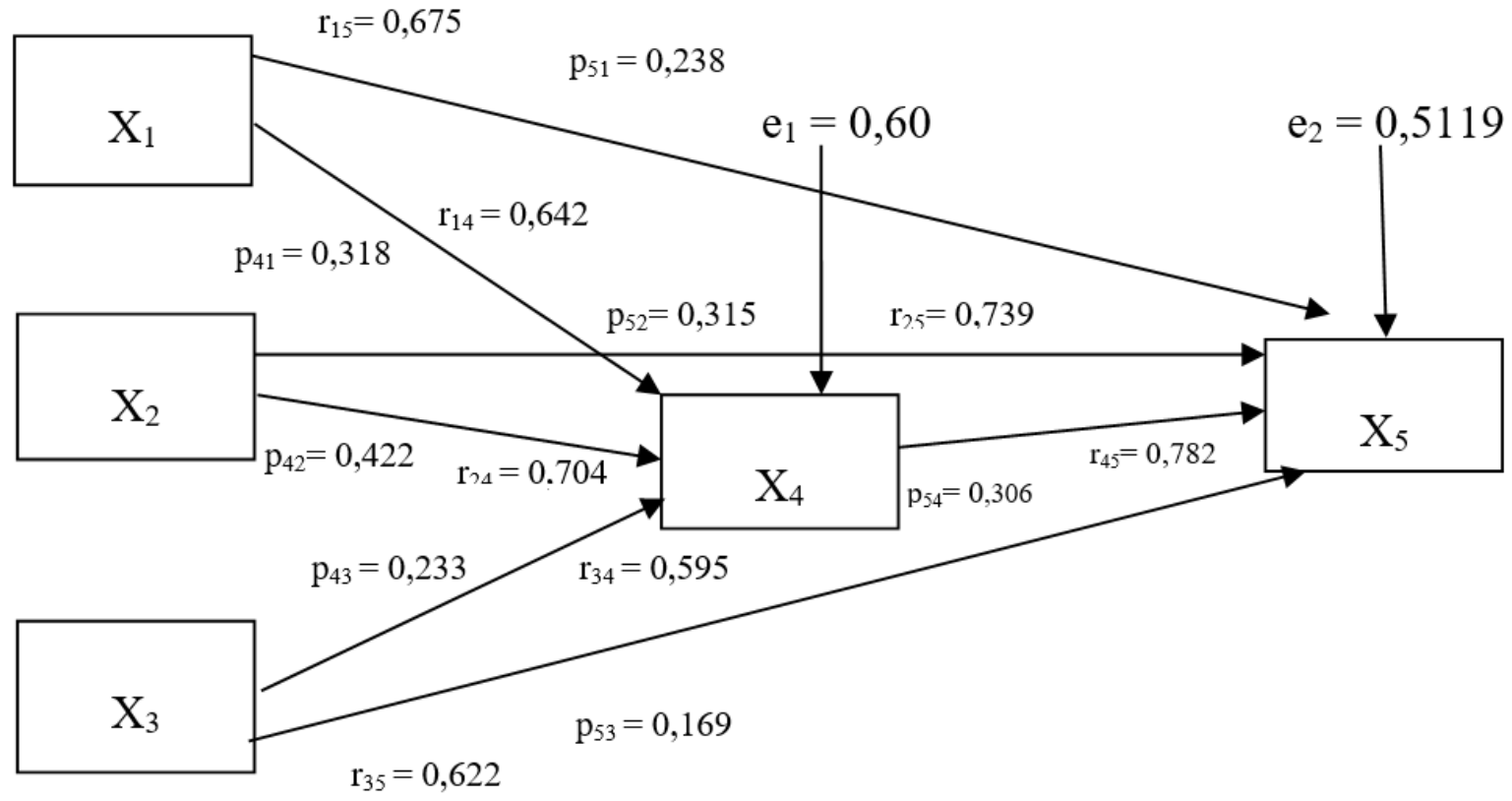

Figure 1 Research Variable Path Diagram Table 1.

Statistical computation of correlation coefficients and path coefficients following testing are summarized in

Table 1 Summary of Calculation Results for Path Coefficients

\begin{tabular}{|c|c|c|c|c|c|}
\hline Number of $\backslash$ Hypothesis & Coefficient Correlation* & Path Coeffecient & $\mathrm{T}_{\text {count }}$ & $\mathrm{T}_{\text {table }}$ & Information \\
\hline 1 & $r_{14}=0,642$ & $\mathrm{p}_{41}=0,318$ & 5,275 & 1,976 & Mean Path \\
\hline 2 & $r_{24}=0,704$ & $\mathrm{p}_{42}=0,422$ & 6,779 & 1,976 & Mean Path \\
\hline 3 & $r_{34}=0,595$ & $\mathrm{p}_{43}=0,233$ & 3,875 & 1,976 & Mean Path \\
\hline 4 & $r_{15}=0,675$ & $\mathrm{p}_{51}=0,238$ & 4,236 & 1,976 & Mean Path \\
\hline 5 & $r_{25}=0,739$ & $\mathrm{p}_{52}=0,315$ & 5,163 & 1,976 & Mean Path \\
\hline 6 & $r_{35}=0,622$ & $\mathrm{p}_{53}=0,169$ & 3,121 & 1,976 & Mean Path \\
\hline 7 & $r_{45}=0,782$ & $\mathrm{p}_{54}=0,306$ & 4,311 & 1,976 & Mean Path \\
\hline
\end{tabular}

Thus, it can be concluded that school culture $\left(\mathrm{X}_{1}\right)$, horizontal communication $\left(\mathrm{X}_{2}\right)$, management knowledge $\left(\mathrm{X}_{3}\right)$, and work motivation $\left(\mathrm{X}_{4}\right)$ have direct and positive effects on teacher performance $\left(\mathrm{X}_{5}\right)$.

In accordance with the path diagram of the research variables obtained based on the theory and the results of hypothesis testing, the relative influence of exogenous variables on endogenous variables. Based on the calculation results, a summary of the relative influence of school culture $\left(\mathrm{X}_{1}\right)$, horizontal communication $\left(\mathrm{X}_{2}\right)$, management knowledge $\left(\mathrm{X}_{3}\right)$, and work motivation $\left(\mathrm{X}_{4}\right)$ has a direct and positive effect on teacher performance $\left(\mathrm{X}_{5}\right)$ as in Table 2 below. 
Table 2 Direct, Non-direct, Total, and Non-Path Effects

\begin{tabular}{|c|c|c|c|c|c|c|c|}
\hline Model & $\begin{array}{c}\text { Exogenous Variable } \\
\text { to Endogenous } \\
\text { Variable }\end{array}$ & \multicolumn{3}{|c|}{ Casual Effect } & \multicolumn{2}{c|}{ Non Path } & Correlation \\
\cline { 2 - 7 } & & Direct & $\begin{array}{c}\text { Indirect } \\
\text { trough } \mathrm{X}_{4}\end{array}$ & $\begin{array}{c}\text { Total } \\
\text { Effect }\end{array}$ & $\mathrm{U}$ & $\mathrm{S}$ & \\
\hline \multirow{4}{*}{$1^{\mathrm{a}}$} & $\mathrm{X}_{1}$ to $\mathrm{X}_{4}$ & 0,318 & - & 0,318 & 0,324 & & 0,642 \\
\cline { 2 - 7 } & $\mathrm{X}_{2}$ to $\mathrm{X}_{4}$ & 0,422 & - & 0,422 & 0,282 & & 0,704 \\
\cline { 2 - 8 } & $\mathrm{X}_{3}$ to $\mathrm{X}_{4}$ & 0,233 & - & 0,233 & 0,363 & & 0,595 \\
\hline \multirow{3}{*}{$2^{\mathrm{b}}$} & $\mathrm{X}_{1}$ to $\mathrm{X}_{5}$ & 0,238 & 0,196 & 0,434 & 0,240 & & 0,675 \\
\cline { 2 - 8 } & $\mathrm{X}_{2}$ to $\mathrm{X}_{5}$ & 0,315 & 0,215 & 0,530 & 0,208 & & 0,739 \\
\cline { 2 - 8 } & $\mathrm{X}_{3}$ to $\mathrm{X}_{5}$ & 0,169 & 0,182 & 0,351 & 0,271 & & 0,622 \\
\hline
\end{tabular}

To find out the magnitude of influence between school culture $\left(\mathrm{X}_{1}\right)$, horizontal communication $\left(\mathrm{X}_{2}\right)$, management knowledge $\left(\mathrm{X}_{3}\right)$, work motivation $\left(\mathrm{X}_{4}\right)$ (model I), and the magnitude of influence between school culture $\left(\mathrm{X}_{1}\right)$, horizontal communication $\left(\mathrm{X}_{2}\right)$, knowledge management $\left(\mathrm{X}_{3}\right)$, and work motivation $\left(\mathrm{X}_{4}\right)$ on Teacher Performance $\left(\mathrm{X}_{5}\right)$ (model II) obtained from the summary model specifically the R square figures obtained from the SPSS application program output as follows.

Table 3 Model Summary

\begin{tabular}{|c|c|c|c|c|}
\hline Model & $\mathrm{R}$ & R Square & $\begin{array}{c}\text { Adjusted R } \\
\text { Square }\end{array}$ & $\begin{array}{c}\text { Std. Error of the } \\
\text { Estimate }\end{array}$ \\
\hline$I$ & $0.800^{\mathrm{a}}$ & 0.640 & 0.633 & 8.085 \\
\hline$I I$ & $0.859^{\mathrm{a}}$ & 0.738 & 0.731 & 6.718 \\
\hline
\end{tabular}

Based on the data obtained that $\mathrm{KD}=\mathrm{R} 2 \times 100 \%$, it can be calculated the coefficient of determination of Model I of $64 \%$ which means that the influence of school culture $\left(\mathrm{X}_{1}\right)$, horizontal communication $\left(\mathrm{X}_{2}\right)$, knowledge management $\left(\mathrm{X}_{3}\right)$ combined to work motivation $\left(\mathrm{X}_{4}\right)$ ) is $64 \%$ while the remaining $36 \%$ is influenced by other factors. Furthermore, the coefficient of determination of Model II from the calculation results obtained by $74 \%$, which means that the influence of school culture $\left(\mathrm{X}_{1}\right)$, horizontal communication $\left(\mathrm{X}_{2}\right)$, management knowledge $\left(\mathrm{X}_{3}\right)$, and work motivation $\left(\mathrm{X}_{4}\right)$ combined to Teacher Performance $\left(\mathrm{X}_{5}\right)$ is $74 \%$, while the remaining $26 \%$ is influenced by other factors.

\section{DISCUSSION}

The results of this study partially indicate that the school culture variable $\left(\mathrm{X}_{1}\right)$ has a direct positive effect on work motivation $\left(\mathrm{X}_{4}\right)$ with the acquisition that $\mathrm{p}_{41}=0.318$ and significance $>0.05$, it means that Ho is rejected or Ha accepted, so it can be concluded that school culture $\left(\mathrm{X}_{1}\right)$ has a direct positive effect on work motivation $\left(\mathrm{X}_{4}\right)$ of Medan state junior high school teachers. This implies an increase of 1 unit variable school culture increases the variable work motivation of teachers by 0.318 units assuming other variables are considered constant. In general, the work of teachers is divided into two, namely: related to teaching and educating tasks, as well as social tasks. As instructors, teachers provide knowledge (cognitive), attitudes and values and skills. Good and bad teacher performance is determined by various factors, including: organizational climate, achievement motivation and teacher job satisfaction (Falahi, 2005). Good school culture increases work motivation of teachers. School culture ultimately increases the work motivation of the teacher. Culture is a positive influence on the organization if it raises behavior in the right direction, widely permeating members of the organization to follow the applied culture. Furthermore culture negatively affects an organization if it results in behavior in the wrong direction.

The results of this study partially indicate that the horizontal communication variable $\left(\mathrm{X}_{2}\right)$ has a direct positive effect on work motivation $\left(\mathrm{X}_{4}\right)$ of teachers with the acquisition that $\mathrm{p}_{42}=0.422$ and significance $>0.05$, it means that $\mathrm{Ho}$ is rejected or $\mathrm{Ha}$ is accepted, so it can be concluded that horizontal communication $\left(\mathrm{X}_{2}\right)$ has a direct positive effect on work motivation $\left(\mathrm{X}_{4}\right)$ of the teacher. This implies an increase of 1 unit variable Horizontal communication increases the teacher's work motivation variable by 0.422 units assuming other variables are considered constant.

The results of this study partially indicate that the variable Knowledge management $\left(\mathrm{X}_{3}\right)$ has a direct positive effect on work motivation $\left(\mathrm{X}_{4}\right)$ of Medan State Junior High School Teachers with the acquisition that $\mathrm{p}_{43}=0.233$ and significance $>0.05$, it means that Ho is rejected. Thus, Ha is accepted. It can be concluded that Knowledge management $\left(\mathrm{X}_{3}\right)$ has a direct positive effect on work motivation $\left(\mathrm{X}_{4}\right)$ of Medan State Junior High Teachers. This implies an increase of one unit variable of Knowledge management increases the variable of work motivation of teachers by 0.233 units assuming other variables are considered constant.

The results of this study partially indicate that the school culture variable $\left(\mathrm{X}_{1}\right)$ has a direct and positive effect on Teacher Performance $\left(\mathrm{X}_{5}\right)$ of Medan state junior high school with the acquisition that $\mathrm{p}_{51}=0.238$ and significance $>0.05$, it means that $\mathrm{Ho}$ is rejected or Ha is accepted, so it can be concluded that school culture $\left(\mathrm{X}_{1}\right)$ has a direct and positive effect on Teacher Performance $\left(\mathrm{X}_{5}\right)$. This implies an increase of 1 unit of school culture 
variables increases teacher Performance variable by 0.238 units assuming other variables are considered constant.

The results of this study partially indicate that the horizontal communication variable $\left(\mathrm{X}_{2}\right)$ has a direct and positive effect on Teacher Performance $\left(\mathrm{X}_{5}\right)$ of Medan City Middle School Teachers with the acquisition that $\mathrm{p}_{52}$ $=0.315$ and significance $>0.05$, it means that Ho is rejected or Ha is accepted, so it can be concluded that horizontal communication $\left(\mathrm{X}_{2}\right)$ has a direct and positive effect on Teacher Performance $\left(\mathrm{X}_{5}\right)$ of Medan state junior high school. This implies an increase of 1 unit variable Communication horizontally increases teacher Performance variable by 0.315 units assuming other variables are considered constant.

The results of this study partially indicate that the variable Knowledge management $\left(\mathrm{X}_{3}\right)$ has a direct and positive effect on Teacher Performance $\left(\mathrm{X}_{5}\right)$ of Medan state junior high school teachers with the acquisition that $\mathrm{p}_{53}=0.169$ and significance $>0.05$, it means that Ho is rejected or Ha is accepted, so it can be concluded that Knowledge Management $\left(\mathrm{X}_{3}\right)$ has a direct and positive effect on Teacher Performance $\left(\mathrm{X}_{5}\right)$. This implies an increase of 1 unit of variable Management knowledge increases the teacher performance variable by 0.169 units assuming other variables are considered constant.

The results of this study partially show that work motivation $\left(\mathrm{X}_{4}\right)$ has direct and positive influence on work Teacher Performance $\left(\mathrm{X}_{5}\right)$ of Medan state junior high school with the acquisition that $\mathrm{p}_{54}=0.306$ and significance $>$ 0.05, it means that Ho is rejected or Ha accepted, so it can be concluded that work motivation (X4) has a direct and positive effect on work motivation $\left(\mathrm{X}_{4}\right)$ Teacher Performance $\left(\mathrm{X}_{5}\right)$ at sate junior high school in Medan. This implies an increase of 1 unit of work motivation variable increases the teacher performance variable by 0.306 units assuming other variables are considered constant.

The results of this study are in accordance with the research of Mohammed and Doghan (2015). It shows that there is a direct relationship between work motivation and performance. Teachers works better if they are truly motivated. Teachers who succeed because of work motivation will make a valuable contribution to education. The strength or weakness of work motivation depends on the amount of expectations to be achieved. People who have high work needs are happy to assume responsibility, like challenging work, do not avoid competition, are proud of their work and confident in their abilities. This is also in line with research conducted by Zulkifli et al (2014) state that work motivation has a positive effect on teacher performance. Educational institutions that provide motivation to the teacher well will be followed by an increase in teacher performance. Motivation is the provision of movement that creates excitement to work so that someone is willing to work together, work effectively and be integrated with all their efforts.

Thus, the results of research through testing hypotheses that accept the seven proposed research hypotheses have found a new finding in the form of a fixed model or a theoretical model of teacher performance that describes the model as proposed in the Theoretic Model of Research Variables. Based on the results of testing the hypotheses that accept seven research hypotheses proposed as described above, a teacher performance model is developed, which is the development of several theories describing casuistic relationships between research variables that determine teacher performance which is the development of several theories, especially from Colquitt (Integrative Model of Organizational Behavior), LePine, and Wesson(An Organizational Behavioral System).

Based on the results of a theoretical study and the results of an analysis of the structure of associative causal relationships between exogenous variables and endogenous variables, the Performance Model of the teacher is perfectly fit with the data to be implemented adaptively in Medan sate junior high school as in Figure 2 below. 


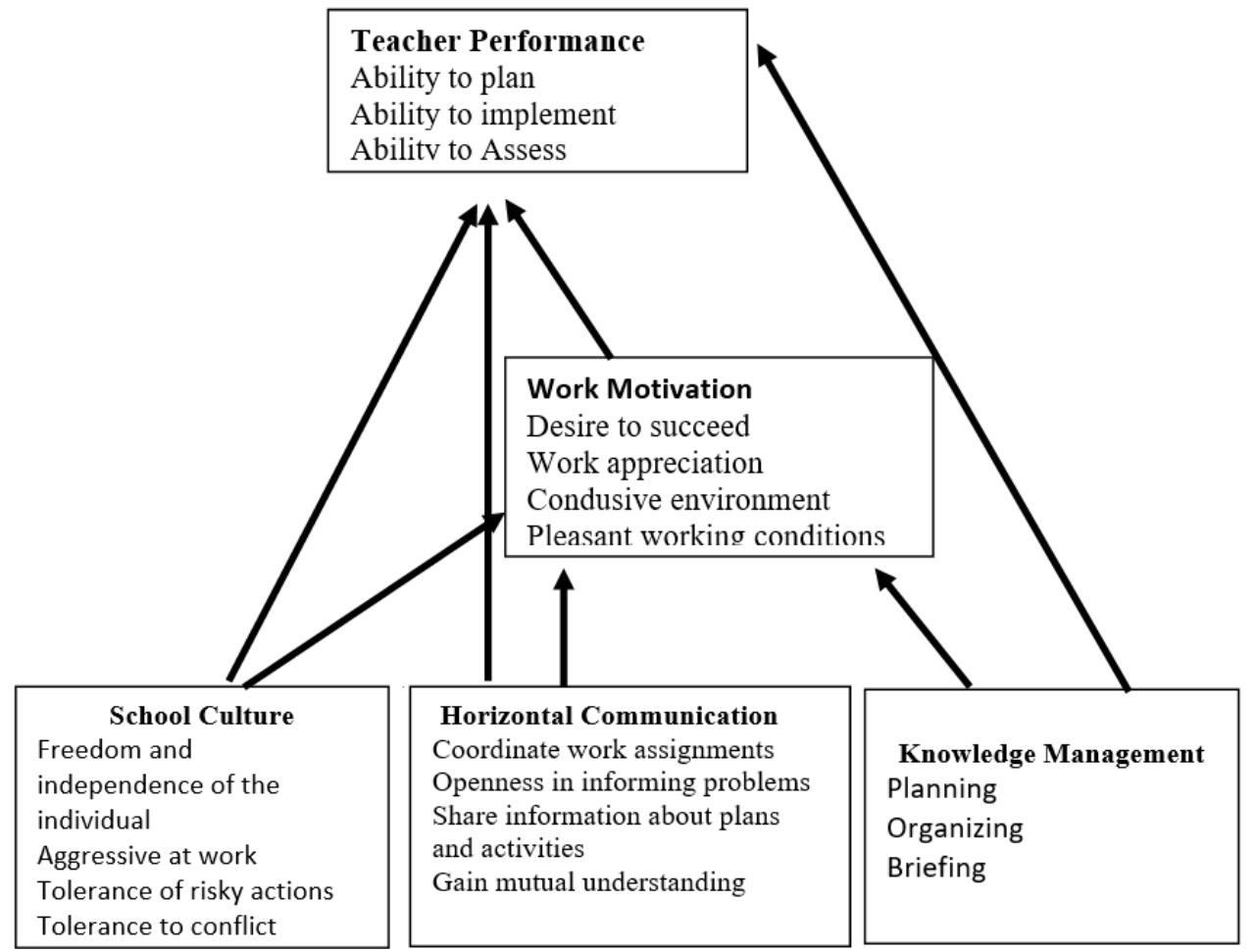

Figure 2 Teacher Performance Models and Affecting Factors

This study explains that improvement in teacher performance can be built through strengthening school culture, horizontal communication, management knowledge and work motivation which can be implemented adaptively at state junior high schools in Medan. Strengthening school culture, horizontal communication, knowledge management causes higher work motivation which in turn makes performance better.

\section{CONCLUSION}

Based on the foregoing descriptions and the results of data analysis and discussion of the results of research conducted, the teacher performance model is built based on the causal associative relationship among the exogenous variables of school culture, horizontal communication, management knowledge, and work motivation with endogenous variables of teacher performance. Teacher performance models of the findings of this study explain that improving teacher performance can be done in two ways, namely: through strengthening school culture, horizontal communication, management knowledge, and work motivation which directly cause teacher performance to be better. In addition, it can also be done through strengthening school culture, horizontal communication, and management knowledge which directly lead to increased work motivation which further enhances better teacher performance.

\section{REFERNCES}

Beaven B, 2003, Training Teachers to be Teachers Trainers: It's more Complicated than You'd Think. In Patricia Byrd and Gayle Nelson (Ed.), Sustaining Professionalism: Professional Development in Language Development in the Language Series, Virginia.

Colcuit, Jason A., Jeffery A., LePine., And Michael J. Wesson. 2009. Organizational Behavior: improving performance and commitment in the workplace. New York: McGraw-Hill.

Davis, Keith and Newstrom, 2000, Behavior in Organizations, Seventh Edition, Erlangga Publisher, Jakarta.

Ministry of National Education. 2004. Improving the Performance of School Principals, Jakarta Directorate General of Primary and Secondary Education, (Directorate of High School Education.

Effendy, Onong. 2000. The Theory and Philosophy of Communication. Bandung: PT. Rosdakarya.

Effendy, Onong. Uchjana. 2003. Communication Science Theory and Practice. Nineteenth Print. Bandung. PT Pemuda Rosdakarya.

Falahy. 2005. Correlation Study Between Organizational Climate and Achievement Motivation with Teacher Job Satisfaction (Study of Samarinda Vocational School teachers). Thesis published (www.geocities.com/guruvalah).

Hamzah B. Uno, 2008, Motivation Theory and Measurement Analysis in the Field of Education, Bumi Aksara, Jakarta. 
Hamalik, Oemar. 2004. Teaching and Learning Process. Bumi Aksara. Jakarta.

Hasibuan, Malayu S.P, 2011. Management: Basics, Understanding, and Problems, Jakarta: Bumi Aksara.

Indrafachrudi. 2000. Performance Assessment Methods and Factors that Affect them. Bandung: Gaulia Indah.

Jumari et al. 2013, The influence of organizational culture, self-efficacy and job satisfaction on the teaching performance of teachers in the district of South Denpasar. Journal of Ganesha University Educational Postgraduate Program Educational Administration Study Program Vol. 4, 2013.

Liana. Y. 2012, Organizational climate and achievement motivation on job satisfaction and teacher performance. Journal of Management and Accounting. Volume 1, Number 2, August 2012.

Mangkunegara, Anwar Prabu. 2012. HR Performance Evaluation, sixth print. Bandung: Refika Aditama.

Manullang.M, 2004. Management of Personnel. Jakarta: Gajah Mada University Press.

Mohammed Al Doghan \& Sukaina Albar2015. "Influence of Motivation Factors on Employees Performance in Private Schools in Saudi Arabia" Journal of Human Resource and Sustainability Studies Vol.03, No. 4

Miftah Toha. 2007. Leadership in Management. Jakarta: PT. Raja Grafindo Persada.

Nawawi, H \& Martini.2003. Effective Leadership. Yogyakarta: UGM Press.

Rivai, Veithzal. 2006. Human Resource Management for Companies: From Practical Theory. Jakarta: PT Raja Grafindo Persada.

Riyadi et al. 2017, The Influence of Communication, Work Motivation and Competence on Job Satisfaction and Its Implications on Lecturer Performance at Private Tourism Colleges in West Java.Journal of Tourism and Hospitality Essentials (THE) Journal, Vol. 7, No. 2, 2017.

Robbins, S. P. 2003 Organizational Behavior, Volume 2, PT. Gramedia Group Index, Jakarta.

Robbins, Stephen P. and Mary Coulter. 2005. Management. 8th Edition. Prentice Hall, New Jersey.

Robbins, S. P \& Timothy A. Judge. 2009. Organizational Behavior New York: Upper Sadle River.

Sagala.Saiful. 2006. Concepts and Meanings of Learning. Bandung: CV. Alfabeta.

Siagian, Sondang P. 2005, Motivation Theory and Its Application. Jakarta: Rineka Cipta.

Sutrisno, Edy, 2013. Human Resources Management. Kencana, Jakarta.

Wijaya and Herminingsih. 2015. The importance of organizational communication, work motivation and compensation to improve teacher performance. (Journal 2 of the Master of Management Study Program at Mercu Buana University. ISSN: 1412-5366. JEAM Vol XIV April 2015).

Zamroni. 2003. Future Education Paradigm. Yogyakarta: Bigraf Publishing.

Zulkifli, et al. 2014. Work Motivation, Certification, Welfare and Teacher Performance. Persona, Indonesian Psychology Journal. May 2014, Vol. 3, No. 02, 148-155 